\title{
回転円板法にょる宮崎市萩の台・たらのき台 一般廃棄物埋立場における浸出水の処理
}

\author{
川本功 - 大田原睦 雄 * 中 山善和 * 壱岐浩 …*
}

\section{〔1〕萩の台処理場における埋立完了前後の水 質変化の推移}

\section{1.はじめに}

昭和43年から埋立を開始し, 昭和51年回転円板法に よる国際第 1 号の污水処理施設を設置した萩の台ごみ 埋立場は，昭和63年 9 月に埋立を完了しました。

この間, 国際第 1 号の回転円板法ということで水質 変化には注目をあつめ, 第 6 回「回転円板法研究シン ポジウム」で，田坂・押川氏が昭和55年から昭和59年 までの水質の変化を報告しました，今回，埋立も完了 しましたので埋立前後の水質の変化を報告します.

\section{2. 水質の変化}

図-1，2，3，4参照

\section{3. 考察}

\section{a) $\mathrm{COD}$}

原水中の C O D は, 平均值力埋立完了前 $69.7 \mathrm{mg} / \ell$ • 埋立完了後 $67.3 \mathrm{mg} / \ell$ で, 変動幅が埋立完了前 $42 \sim$ $120 \mathrm{mg} / \ell$ ・埋立完了後 $41 \sim 100 \mathrm{mg} / \ell$ であった。の ことから, 埋立完了前後 2 年間では C O D に殆ど変化な く, 今後のCODの変化に注目していきたいと思います.

図一 1 から明らかなように, 円板処理水から最終処 理水の間でC O Dが極端に下がっていますが，これか らも，CODは凝集沈殿設備・砂乃過設備・活性炭設 備で原水中の半分以上が除去されていることがわかる.

上記のことから, 埋立完了後 C O D に隇少傾向がな いことから凝集沈殿設備以降の設備は今後重要になっ てくるものと思われます。

$*$ 宮崎市環境事業部 Isao KAWAMOTO

Mutsuo OHTAHARA, Yoshikazu NAKAYAMA, Kohichi IKI
また, 最終処理水については, 平均值が埋立完了前 $16.6 \mathrm{mg} / \ell$ ・埋立完了後 $16.0 \mathrm{mg} / \ell$ で, 変動幅が埋立 完了前 $2.3 \sim 50 \mathrm{mg} / \ell \cdot$ 埋立完了後1.3 34mg $/ \ell$ であ り問題なく処理されています.

b) $\mathrm{BOD}$

原水中の B O D は，平均值か埋立完了前 $34.4 \mathrm{mg} / \ell$ ・ 埋立完了後 $16.3 \mathrm{mg} / \ell$ で，変動幅が埋立完了前5.6

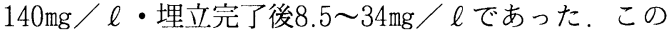
中で，昭和63年 6 月にB O D が極端に高くなっている

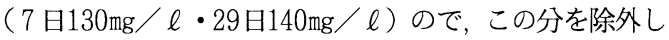
た場合の埋立完了前の平均值及び変動幅は $22.6 \mathrm{mg} / \ell$ ・ $5.6 \sim 57 \mathrm{mg} / \ell$ となっている。このことから，埋立完 了後の方が完了前よりも B O D が低く減少傾向にあり， 今後も減少していくのではないかと思われる。

また，最終処理水については，平均值が埋立完了前 $1.4 \mathrm{mg} / \ell \cdot$ 埋立完了後 $1.6 \mathrm{mg} / \ell$ で, 変動幅が埋立完 了前 $0.5 \sim 3.3 \mathrm{mg} / \ell \cdot$ 埋立完了後 $0.5 \sim 5.6 \mathrm{mg} / \ell$ であ り問題なく処理されています.

C) 窒 素

原水中の $\mathrm{T}-\mathrm{N及び} \mathrm{NH}_{4}-\mathrm{N}$ は, 平均值が埋立完 了前 $86.6 \mathrm{mg} / \ell$ ・埋立完了後 $97.9 \mathrm{mg} / \ell$ 及び埋立完了 前 $78.1 \mathrm{mg} / \ell$ ・埋立完了後 $85.8 \mathrm{mg} / \ell$ で変動幅が埋立 完了前52 170mg $/ \ell \cdot$ 埋立完了後 42 190mg / $\ell$ 及び 埋立完了前 $44 \sim 160 \mathrm{mg} / \ell \cdot$ 埋立完了後39 140mg $/ \ell$ であった。このことから， $\mathrm{T}-\mathrm{N} ・ \mathrm{NH}_{4}-\mathrm{N}$ 共増加 傾向にあり, COD同様, 今後の変化に注目していき たいと思います。

また，脱窒率については, メタノールポンプまたは 脱窒円板の故障により低下している時期がありますが, ほぽ問題なく処理されています。

尚，埋立完了後窒素分が増加傾向にあるので，メ夕 ノールポンプ及び脱窒円板についても今後重要な設備 になるものと思われます。 


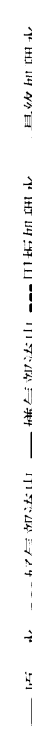

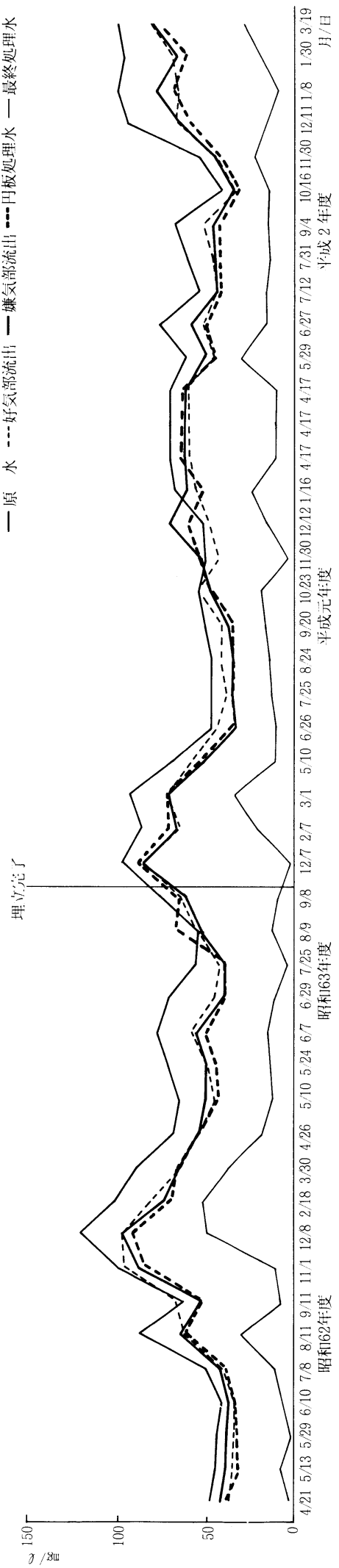

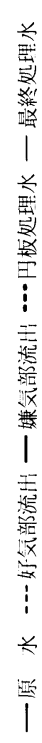

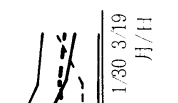

(1)

$\left\langle\begin{array}{l}1 \\ i \\ i\end{array}\right)$

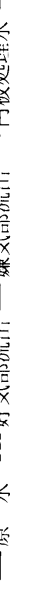

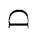

o

$\infty$

$\stackrel{n}{\sim}$ 

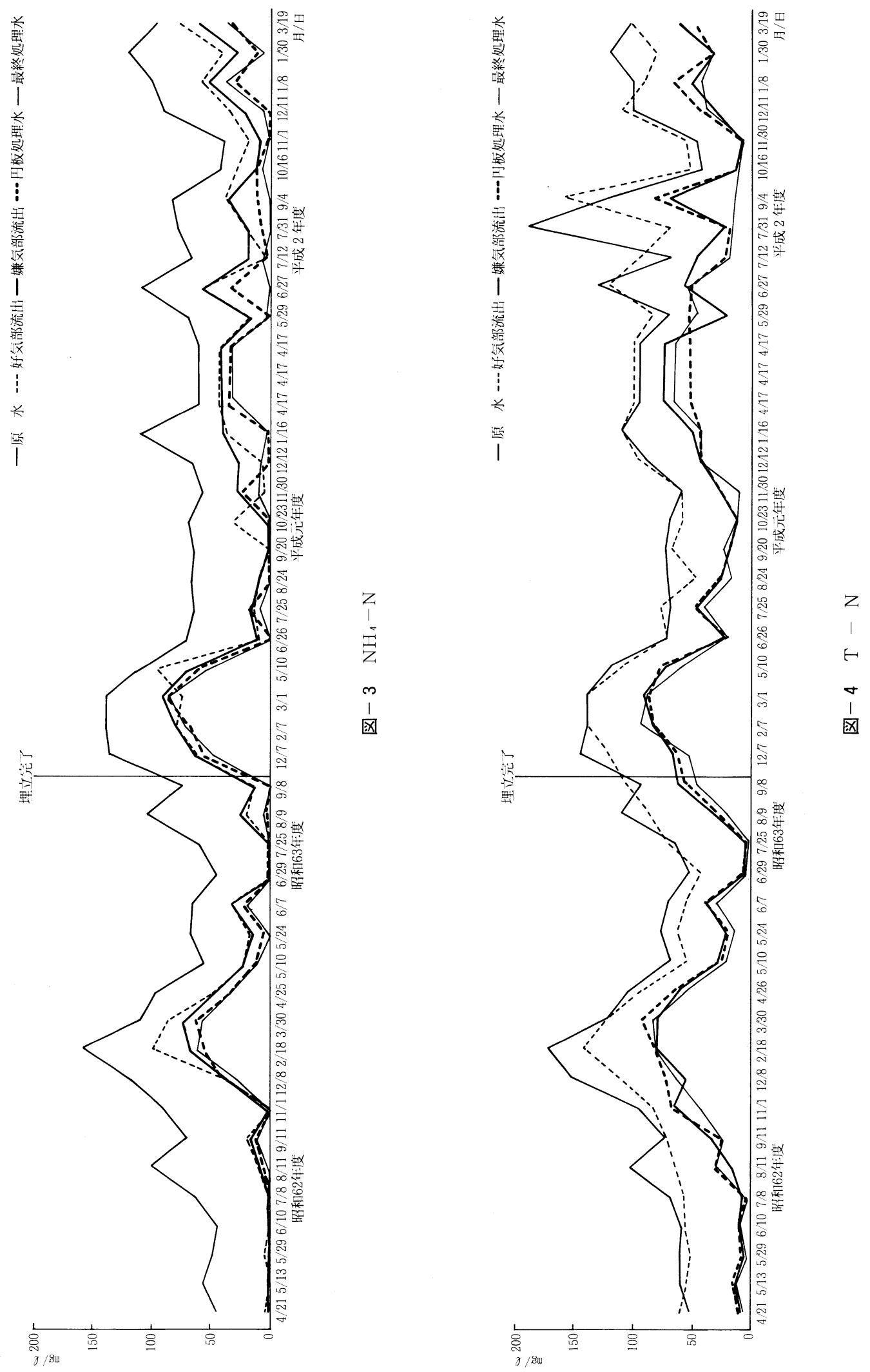


\section{〔2〕宮崎市たらのき台不燃物埋立場における 浸出液処理施設の概要と実績}

\section{1.はじめに}

宮崎市は, 九州の東南部宮崎県のほぼ中央に位置し, 太平洋に面する本土で最す温暖な気候に恵まれた都市 であり，人口約 29 万人を擁する県都として，また政治， 経済，教育，文化の中心都市として発展している。

本市では，経済の成長，市民生活等の向上による廃 菓物量の増大に伴い, 昭和43年から市北部住吉地区山 間部に萩の台ごみ埋立場を開設し，不燃ごみを中心に 埋立を行ってきたが，昭和63年 9 月に埋立を完了した．

これに伴い市西部細江地区山間部に翌10月からたら のき台不燃物埋立場を開設し，不燃ごみの埋立処分を サンドイッチ工法で行っている.

この埋立場は，総面積208,000 m²，埋立容量 $1,660,000$ $\mathrm{m}^{3}$ を有し，また，公害防止の点から浸出液による農作 物等への被害をなくすため，処理能力 $535 \mathrm{~m}^{3} / 1$ 日を 有する処理施設を備えている.

この浸出液処理施設は, 生物処理, 化学処理, 物理 処理の 3 工程からなり，準好気性埋立工法を用いた埋 立地底部のしゃ水シートの上に敷設した有孔ヒューム 管により集水した浸出液を処理し，近くの河川に放流 している.

なお，本埋立場並びに浸出液処理施設は，(侏宮崎衛 生公社に業務委託している。

本文は，たらのき台不燃物埋立場浸出液処理施設の 概要と実績を報告する。

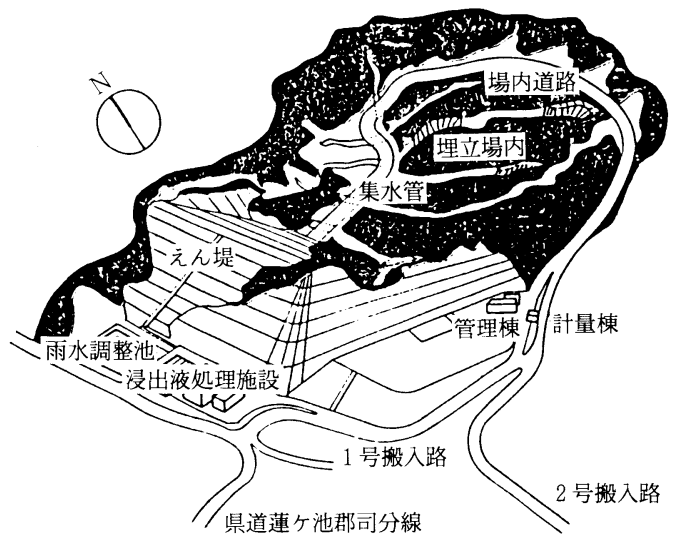

図-5 全体配置図

\section{2. 不燃物埋立場及び浸出液処理施設の概要}

\section{1 不燃物埋立場}

本埋立場は，市西部細江地区山間部の谷間を利用し た総面積20.8ha 埋立容量166万 $\mathrm{m}^{3}$ の処分場で，車によ る搬入後，コンパクタ一等重機を利用して破砕転圧後 サンドイッチ工法により即日覆土埋立を行っている.

平成 2 年度の搬入廃棄物は図 -6 に示すように主に 一般家庭から出る不燃ごみが約28\%を占め次いで建設 廃材の $22 \%$ ，焼却灰の $16 \%$ となっており，全体で年間 約75,800 t 埋立ている.

また, 平成 3 年 5 月から埋立場内に宮崎市リサイク ルセンター（事業主体：宮崎県リサイクル事業協同組 合）を開設し，不燃ごみの中に含まれる空き缶，雑ビ ン，金属類の回収再資源化を図っている.

\section{2 浸出液処理施設}

(1) 設計条件

処理水量は, $535 \mathrm{~m}^{3} /$ 日で, 水質基準は, 表 1 の通 りである。

(2) 施設概要

フローシートは, 図ー 7 に示す.

浸出污水は，地形的落差を利用し，有孔管にて集水 し, 調整槽 $\left(\right.$ 約 $\left.900 \mathrm{~m}^{3}\right)$ に送られる。

最初の処理工程の生物処理は, 半水没型（好気性） 回転円板による硝化部之全水没型（嫌気性）回転円板 による脱窒部からなり, 栄養源として, 硝化部流入時

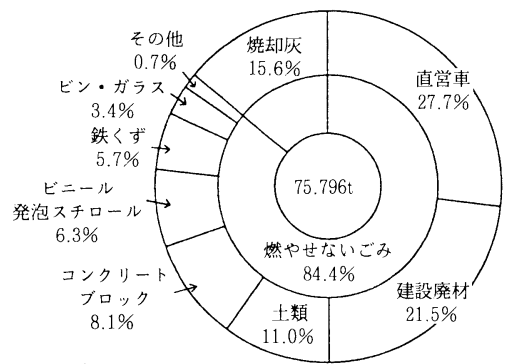

図-6 平成 2 年度ごみの種類による埋立内訳

表 1

\begin{tabular}{|l|c|c|}
\hline 水 質 基 準 & 浸出水 & 処理水 \\
\hline $\mathrm{pH}$ & $6 \sim 9$ & $6.5 \sim 8.5$ \\
$\mathrm{BOD}(\mathrm{mg} / \ell)$ & 100 & 5 以下 \\
$\mathrm{COD}(\mathrm{mg} / \ell)$ & 150 & 10 以下 \\
$\mathrm{SS}(\mathrm{mg} / \ell)$ & 100 & 10 以下 \\
$\mathrm{T}-\mathrm{N}(\mathrm{mg} / \ell)$ & 150 & 10 以下 \\
$\mathrm{NH}_{4}-\mathrm{N}(\mathrm{mg} / \ell)$ & 135 & 1 以下 \\
\hline
\end{tabular}




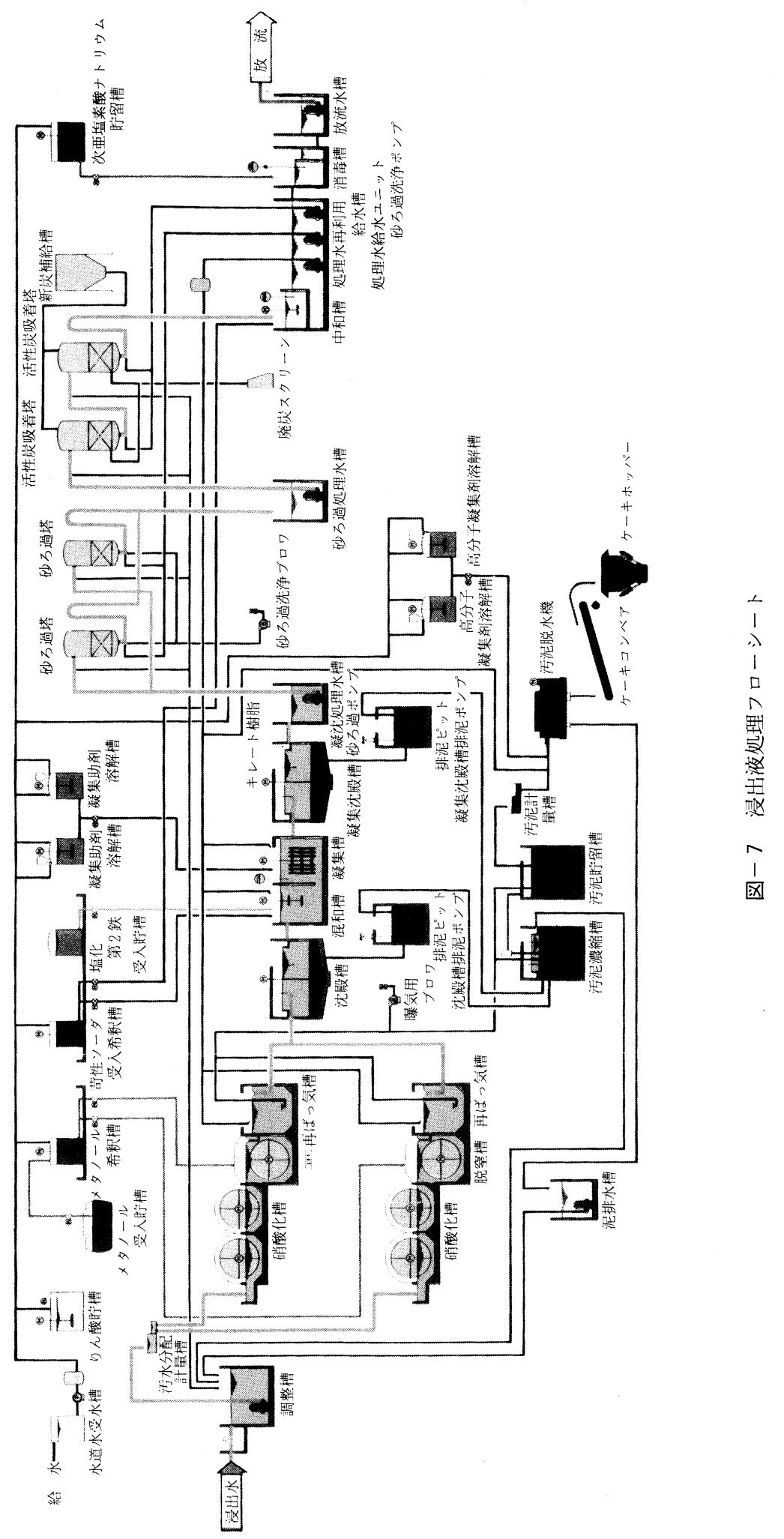


に $\mathrm{H}_{2} \mathrm{PO}_{4}$ を脱窒部で $\mathrm{CH}_{3} \mathrm{OH}$ を添加する，さらに，再 曝気槽で残存 $\mathrm{CH}_{3} \mathrm{OH}$ の除去之窒素ガスの脱気を行う.

次の化学処理では, 沈殿槽で S S 分と脱窒工程で発 生した余剩污泥の分離をおこなった処理水を，混和槽 之凝集槽で $\mathrm{FeCl}_{2}$ ２凝集助剂を添加することにより， フロックを形成させ，凝集沈殿槽にて，沈降分離し上 澄水をさらに分離する。

物理処理では, 砂ろ過塔, 活性炭吸着塔を 通して，微細なフロックと残存C O D 成分を 除去する.さうに, 中和槽で $\mathrm{pH}$ 調整後消毒 槽にて滅菌後放流している。

さらに, 沈殿槽と凝集沈殿槽で出る沈殿槽 で出る污泥は，濃縮槽で濃縮後連続式遠心脱 水機にて脱水する.

・半水没型（好気性）回転円板（硝酸化槽）

数 量………2 基 $\times 2$ 系列

円板径……… $3.6 \mathrm{~m}$

円板表面積 $\cdots 7,990 \mathrm{~m}^{2} /$ 基

・全水没型（嫌気性）回転円板（脱窒槽）

数 量………1 基 $\times 2$ 系列

円板径……… $3.6 \mathrm{~m}$

円板表面積 $\cdots 6,700 \mathrm{~m}^{2} /$ 基

・砂万過塔 鋼板製円筒型圧力式万過器

寸法及び数量 $\cdots$ 内径 $1.35 \mathrm{~m} \times$ 高さ $3.05 \mathrm{~m}$ $\times 2$ 塔

万過面積……1.43 m²

・活性炭吸着塔 鋼板製円筒型吸着塔

寸法及び数量 $\cdots$ 内径 $1.75 \mathrm{~m} \times$ 高さ $4.0 \mathrm{~m}$ $\times 2$ 塔

通水方法 $\cdots \cdots \cdot 2$ 塔シリーズ通水

\section{3. 運 転 実 績}

\section{1 運転 水質}

生物処理, 化学処理及び物理処理の各処理工 程におけるBOD， COD， T - N , $\mathrm{NH}_{4}-\mathrm{N}$ の除去状況について埋立開始から約 2 年間の 分析結果を図ー8〜11に示す.
(1) $\mathrm{BOD}$
図一 8

浸出液中の $\mathrm{B} O \mathrm{O}$ 濃度は，かなり变動が大 きく3.5 350mg $/ \ell$ (平均 $96 \mathrm{mg} / \ell$ ) の範囲 にあった．特に春から夏期にかけて，急激に 増加しており降雨量の多い時期に高くなる傾 向にある. 処理状況は，好気部円板流出部で 平均 $94 \%$ 程度まで処理され最終処理水では，
平均 $1.5 \mathrm{mg} / \ell$ 之設計基準を十分クリアーしており, 処理は非常に良好である。
(2) 図 -9

C ODの場合も B OD同様变動が激しく, 13〜 76mg／ $\ell($ 平均 $43 \mathrm{mg} / \ell$ ) の範囲であった。変化は, B O D 之同様春加夏期の雨の多い時期に増加の傾向にあっ た. 処理状況は，好気部円板流出部で平均約 $60 \%$ ，最

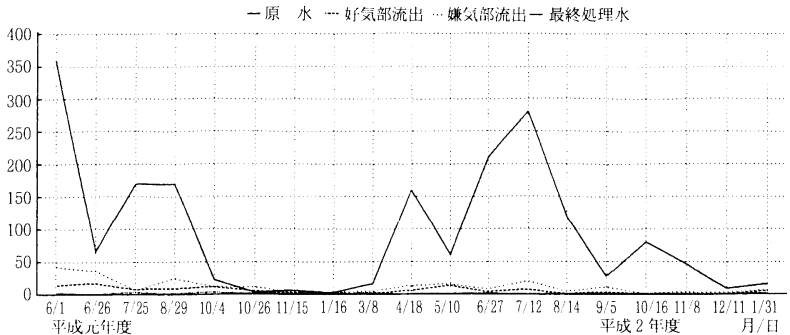

図－８水質検查（たらのき台） B O D

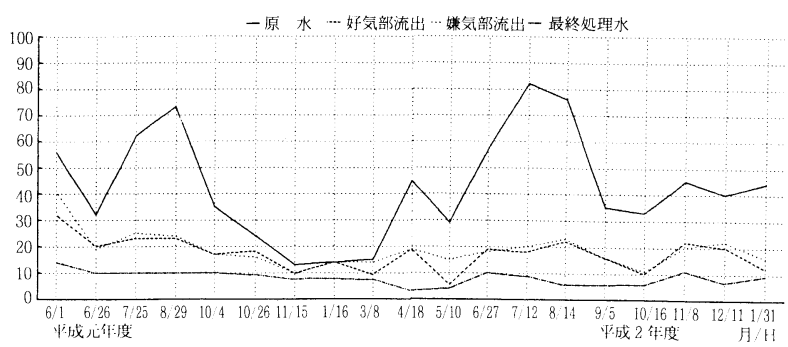

図－9 水質検査（たらのき台） C O D

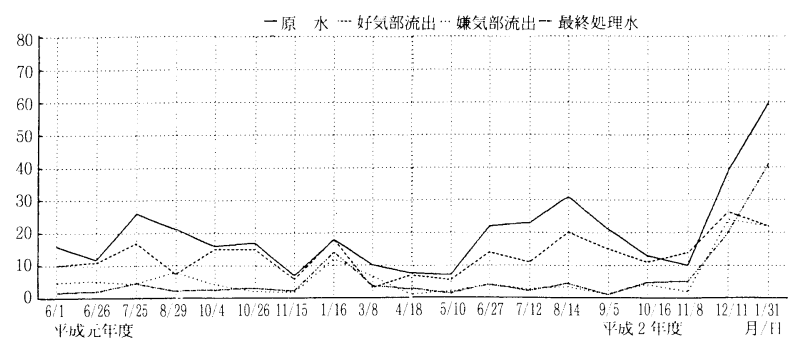

図－10 水質検査（たらのき台） $\mathrm{T}-\mathrm{N}$

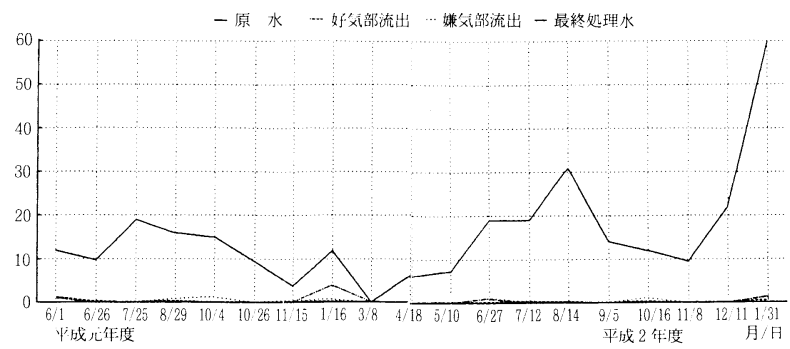

図－11 水質検査（たらのき台） $\mathrm{NH}_{4}-\mathrm{N}$ 


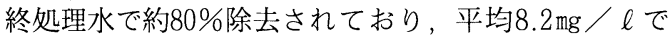
設計基準 $10 \mathrm{mg} / \ell$ を十分クリアーしている.

(3) $\mathrm{T}-\mathrm{N} \cdots \cdots \cdots \cdots \cdot$ 図 -10

浸出液中の $\mathrm{T}-\mathrm{N}$ は, 埋立当初のため, 平均 $19.8 \mathrm{mg} /$ $\ell$ で比較的低く埋立 1 年目は, 比較的低く安定したが, 2 年目で後半から增加の傾向にあり， 1 月には， $60 \mathrm{mg} /$ ととなった。

平成元年度平均で, $15.9 \mathrm{mg} / \ell$, 平成 2 年度で, 23.4 $\mathrm{mg} / \ell$ と増加の傾向にあり, 埋立が進むに連れて増加 していくものと予想される.

処理状況は，好気部円板流出部で平均約34\%，嫌気 部円板流出部で平均約70\%除去されており，最終処理 水で平均 $6.4 \mathrm{mg} / \ell$ で設計基準 $10 \mathrm{mg} / \ell$ を十分クリアー している.ただ， 2 年目の後半の 12 月， 1 月に一時的 に処理状況が悪くなったが，これは，T－Nの急激な 增加に伴い脱窒菌の栄養源であるメ夕ノール添加量の 不足によるものと考えられる. 今後も浸出液中の T Nが増减すると予想されるので，その都度メタノール 添加量の調整をしていく必要があると思われる.

(4) $\mathrm{NH}_{4}-\mathrm{N} \cdots \cdots \cdots \cdots \cdot$ 図-11

$\mathrm{NH}_{4}-\mathrm{N}$ の場合も, $\mathrm{T}-\mathrm{N}$ と同様に 2 年間の平均 で浸出液中に, $15.6 \mathrm{mg} / \ell$ と低く, 年度ごとにみると, 平成元年度は, 平均 $10.8 \mathrm{mg} / \ell$, 平成 2 年度で, 20.0 $\mathrm{mg} / \ell$ 之増加の傾向にある. 処理状況は，好気部円板 流出部で平均約 $98 \%$ と除去されており，硝化菌による 硝化が良好に行われていることを示している。
表 2 平成 2 年度使用薬品量及び電力量

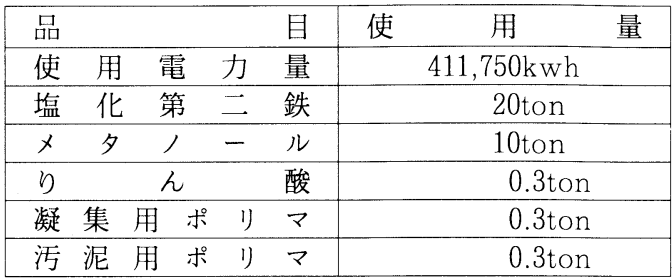

\section{2 維持管理}

平成 2 年度に使用した薬品量及び電力量を表 2 に示 す.なお，活性炭の再生は，3回（1回 1 塔 $2,800 \mathrm{~kg}$ ) 行った.

また, 浸出液 $1 \mathrm{~m}^{3}$ 当りの処理コストは, 薬品, 電力

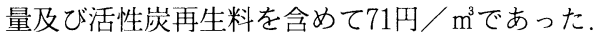

\section{4.おわりに}

宮崎市たらのき台不燃物埋立場における浸出液処理 施設について運転開始後 2 年間の運転実績を報告した.

各項目の除去状況は，最終処理水でB O D 94\%， C O D 80\%， T- N70\%， $\mathrm{NH}_{4}-\mathrm{N} 98 \%$ と非常に良く 平均してすべての項目について設計基準を十分にクリ アーしていた。 また, 浸出液の変動に対しても, 安定 した処理を続けており，放流先の地域住民を安心させ るのに十分な水質となっている.

今後も安定した水処理を行うため, 日夜委託業者職 員共々努力していきたいと考えています.

\section{海外環境情報}

\section{原発事故によるストレスも癌の原因に なるか}

Did post-accident stress raise cancer rates?

H25101360

American Journal of Public Health 誌の 1991 年6月号に, 1979年のスリーマイル島（TM I）原子 力発電所事故による精神的なストレスのために，付近 住民の癌の発生が一時期（1982～83）に增加したとい う研究が紹介されている.

この研究では, ストレスの指標として原発からの距 離を用い, T M I 原発から $10 \mathrm{mile}$ 以内の住民に関す る病院のカルテや死亡診断書を1975年から1985年まで
再検討し，年間の癌発生率や死亡率を調べた。その結 果，原発に最む近い地域では癌の発生が1982年に上昇 しているが，1984年には事故前のレベルまで低下し， 1985年では原発から遠い地域よりあ低い值であること を報告している，一方，原発の近くの住民の癌による 死亡率は事故以前と比べ増加の傾向はなかった。

著者らは, 癌の増加の原因として放射線による可能 性を否定しており，この現象はスクリーニング効果で 説明されたという，すなわち，事故による癌を恐れる 住民はしばしば医師を訪ねるため，潜在的なガンの発 見が可能になる. 癌発生率の増加に対し癌による死亡 率が増えていないことがこの説を支持している。 C0348B Nucl News 34 [ 9 ) 29 (1991)

（日本科学技術情報センター許可第文0321号） 